\title{
Influence of hydrochemical indicators on the age and density of bivalve molluscs, spread in the lower reaches of the Zarafshan river
}

\author{
R. Masharipov ${ }^{1 *}, S$. Suyarov $^{1}, N$. Khasanov $^{2}, T$. Jabbarova ${ }^{3}, F$. Jalilov ${ }^{1}, F$. Turikhanov ${ }^{1}$, \\ $D$. $\operatorname{Kosimov}^{1}, I$. Tuinazarova ${ }^{4}$, and $F$. Shodmonov ${ }^{1}$ \\ ${ }^{1}$ Samarkand State University, 140104 Samarkand, Uzbekistan \\ ${ }^{2}$ Navoi State Pedagogical University, 210100 Navoi, Uzbekistan \\ ${ }^{3}$ Karshi State University, 180103 Karshi, Uzbekistan \\ ${ }^{4}$ Jizzakh Polytechnic Institute, 100130, Jizzakh, Uzbekistan
}

\begin{abstract}
Hydrochemical parameters of water in ecosystems of Gijdivan district of Bukhara region: O2 content 4,9 $\pm 0,5 \mathrm{mg} / 1, \mathrm{Cl} 2312 \pm 14 \mathrm{mg} /$, mineralization - 992-1402 $\mathrm{mg} / 1$ and oil products about $0,6-0,8 \mathrm{mg} / 1$, it turned out that the amount of these elements in the water exceeds the permissible norm. The following conclusions were made on the basis of the study of the status of the species listed in the "Red Book" in aquatic ecosystems of the lower reaches of the Zarafshan river. We found that the population of the species Colletopterum and Corbicula in the village of Sultanabad in the Navoi region is a growing population, while the population of the species Colletopterum and Corbicula in the Gijduvan region of the Bukhara region is decreasing.
\end{abstract}

Acute changes in the global ecological situation today are largely the result of anthropogenic forces, this affects bioecological properties of the animal world, as well as mollusks, as a result, their habitats disappear, which leads to a change in the population of common species and the disappearance of rare and endangered species.

Such foreign scientists as James H. Thorp., Alanp Covich; Aldridge; Bouchet; Huber Markus; Bogan; Annabelle Cuttelod et al. Maria Haws; Mamangkey et al.; Rahayu et al.; Sata Yoshida Srie Rahayu made significant contributions to the study of molluscs $[1,2,3,4]$. In Uzbekistan I.Z. Izzatullaev and Kh.T. Boymurodov analyzed spread, density and ecological groups of mollusks.

Study of mollusks and collection of materials in the reservoirs of the lower reaches of the Zarafshan river started in 2018. Materials for research were collected from 2018 to 2021. Molluscs were researched according to the methods presented by Starobogatov, Izzatullaev; Rijinashvili; Izzatullaev, Boymurodov [3,4].

In order to compare the state of populations of bivalve mollusks listed in the "Red Book" of the Republic of Uzbekistan and spread in aquatic ecosystems of the lower reaches of the Zarafshan river, we conducted research in two territories $[5,6,7,8]$. The first territory

\footnotetext{
* Corresponding author: Sulton.Suyarov@mail.ru
} 
is the area of Sultanabad village of Navoi region, the second is the area of Gijdivan district, Bukhara region. Hydrochemical parameters of water in aquatic ecosystems of the Sultanabad village of Navoi region: $\mathrm{O}_{2}$ amount $-4,8 \pm 0,4 \mathrm{mg} / 1, \mathrm{Cl}_{2}-282 \pm 14 \mathrm{mg} / \mathrm{l}$, salinity - 842-1012 mg / 1 and oil products about $0,4-0,6 \mathrm{mg} / 1$, it was found that the amount of these elements in water was near the permissible limit. It was revealed that Colletopterum bactrianum has a density of $0,6 \pm 0,1$ at the age of 2-3 years, $0,5 \pm 0,3$ - at the age of 4-5 years, 0,2 $\pm 0,2$ - at the age of 6-7 years , 8-9 years old have not been met, Colletopterum cyreum sogdianum has a density of $1,1 \pm 0,3$ at the age of 2-3 years, $0,9 \pm$ 0,2 - at the age of 4-5 years, $0,6 \pm 0,1$ - at the age of 6-7 years and $0,4 \pm 0,1$ at the age of 89 years, Corbicula cor has a density of 1,4 $\pm 0,4$ at the age of 2-3 years and 1,1 $\pm 0,2$ at the age of $4-5$ years old, Corbicula purpurea has a density of 2,1 $\pm 0,3$ at 2-3 years of age and $0,9 \pm 0,2$ at 4-5 years of age, Corbicula fluminalis has a density of 1,6 $\pm 0,3$ at $2-3$ years old and 0,8 $\pm 0,1$ at the age of 4-5 years (Table 1 ).

Table 1. Influence of hydrochemical indicators on age and population density of bivalve mollusks included in the "Red Book", widespread in the lower reaches of the Zarafshan River. $(\mathrm{n}=10)$

\begin{tabular}{|c|c|c|c|c|c|c|c|c|}
\hline \multirow[b]{2}{*}{$\begin{array}{l}\text { Types of } \\
\text { molluses }\end{array}$} & \multicolumn{8}{|c|}{ The territory of Sultanabad village, Navoi region (age and density m2) } \\
\hline & $\begin{array}{c}\mathbf{O 2} \\
\text { (oxygen) } \\
(\mathbf{m} / \mathbf{g})\end{array}$ & \begin{tabular}{|c}
$\mathbf{C l 2}$ \\
(chlorine) \\
(m/g)
\end{tabular} & $\begin{array}{l}\text { Minerali- } \\
\text { zation } \\
(\mathbf{m} / \mathbf{g})\end{array}$ & $\begin{array}{c}\text { Oil } \\
\text { products } \\
(\mathrm{mg} / \mathrm{l})\end{array}$ & $\begin{array}{c}2-3 \\
\text { years }\end{array}$ & $\begin{array}{c}4-5 \\
\text { years }\end{array}$ & $\begin{array}{c}6-7 \\
\text { years }\end{array}$ & $\begin{array}{c}8-9 \\
\text { years }\end{array}$ \\
\hline $\begin{array}{c}\text { Colletopterum } \\
\text { bactrianum }\end{array}$ & \multirow{5}{*}{$4,8 \pm 0,4$} & \multirow{5}{*}{$282 \pm 14$} & \multirow{5}{*}{$842-1012$} & \multirow{5}{*}{$0,4-0,6$} & $0,6 \pm 0,1$ & $0,5 \pm 0,3$ & $0,2 \pm 0,2$ & - \\
\hline $\begin{array}{l}\text { Colletopterum } \\
\text { cyreum } \\
\text { sogdianum }\end{array}$ & & & & & $1,1 \pm 0,3$ & $0,9 \pm 0,2$ & $0,6 \pm 0,1$ & $0,4 \pm 0,1$ \\
\hline Corbicula cor & & & & & $1,4 \pm 0,4$ & $1,1 \pm 0,2$ & - & - \\
\hline $\begin{array}{l}\text { Corbicula } \\
\text { purpurea, }\end{array}$ & & & & & $2,1 \pm 0,3$ & $0,9 \pm 0,2$ & - & - \\
\hline $\begin{array}{l}\text { Corbicula } \\
\text { fluminalis }\end{array}$ & & & & & $1,6 \pm 0,3$ & $0,8 \pm 0,1$ & - & - \\
\hline $\begin{array}{c}\text { Average } \\
\text { acceptable } \\
\text { level }\end{array}$ & $\begin{array}{l}\text { K-4 } \\
\text { Yo-6 }\end{array}$ & 300 & 1000 & 0,5 & & & & \\
\hline
\end{tabular}

In the aquatic ecosystems of the territory of Sultanabad village, Navoi region, the hydrochemical parameters of water, amount of $\mathrm{O}_{2}, \mathrm{Cl}_{2}$, mineralization and the amount of oil products in the water are approximately at the average permissible level, it was noted that in these aquatic ecosystems the distribution, density, nutrition, growth and variability of shells of bivalve mollusks are not adversely affected. It was observed that in the population the density of 2-3 years-olds is 6-7, the density is lower in 8-9-year-olds. The high density of youth indicates that this population has the potential for recovery in the future. This is due to the fact that young mollusks reproduce and recover rapidly in the population.

The influence of human economic activity on the lower reaches of the Zarafshan river dates back to ancient times. This effect is observed in the hydrological regime of the river, which changes the quantity and quality of water resources. At present, part of the river in the Bukhara region is fed mainly by return water from cultural fields, industrial wastewater and groundwater. Rapid development of agriculture and industry in the Samarkand, Bukhara and Navoi regions since the $1960 \mathrm{~s}$ has led to a complete depletion of surface and groundwater resources in the region, their pollution with industrial waste and sewage.

Hydrochemical parameters of water in ecosystems of Gijduvan district of Bukhara region: $\mathrm{O}_{2}$ content $-4,9 \pm 0,5 \mathrm{mg} / 1, \mathrm{Cl}_{2}-312 \pm 14 \mathrm{mg} / 1$, salinity $-992-1402 \mathrm{mg} / 1$ and 
oil products about $0,6-0,8 \mathrm{mg} / 1$, it turned out that the amount of these elements in water exceeds the permissible norm.

This affects the density of the shellfish. It was studied that Colletopterum bactrianum has a density of $0.3 \pm 0,1$ at the age of 2-3 years, $0,4 \pm 0,3$ - at the age of 4-5 years, 6-7 years, $8-9$ years have not been met, Colletopterum cyreum sogdianum has a density of $0,5 \pm$ 0,1 at 2-3 years, $0,7 \pm 0,1-$ at the age of 4-5 years, $0,9 \pm 0,2-$ at the age of 6-7 years, 8-9 years have not been met, Corbicula cor has a density of $0,4 \pm 0,2$ at the age of 2-3 years and 0,6 $\pm 0,3$ at the age of 4-5 years, Corbicula purpurea has a density of 0,7 $\pm 0,1$ at the age of 2- 3 years old, $0,9 \pm 0,2$ at the age of 4-5 years, Corbicula fluminalis has a density of $0,8 \pm 0,2$ at the age of 2-3 years and 1,1 $\pm 0,3$ at the age of $4-5$ years.

As the level of salinity of river water increases, the amount of toxic ions (magnesium, sodium, potassium, sulfates and chlorides) in them also changes depending on the length and time of the river, as well as the water content of the year. As a result, the water quality of many rivers, including the Zarafshan, changes not only in the lower reaches, but also in the middle reaches.

Hydrochemical parameters of water in ecosystems of Gijdivan district of Bukhara region: $\mathrm{O}_{2}$ content 4,9 $\pm 0,5 \mathrm{mg} / 1, \mathrm{Cl}_{2} 312 \pm 14 \mathrm{mg} / 1$, mineralization - 992-1402 $\mathrm{mg} / 1$ and oil products about $0,6-0,8 \mathrm{mg} / 1$, it turned out that the amount of these elements in the water exceeds the permissible norm.

The following conclusions were made on the basis of the study of the status of the species listed in the "Red Book" in aquatic ecosystems of the lower reaches of the Zarafshan river. We found that the population of the species Colletopterum and Corbicula in the village of Sultanabad in the Navoi region is a growing population, while the population of the species Colletopterum and Corbicula in the Gijduvan region of the Bukhara region is decreasing.

\section{References}

1. Kh.T.Boymurodov, Uzbek Biological journal, 5, 41-42 (2011)

2. A. E. Bogan, Hydrobiologia, 595, pages139-147 (2008).

3. Kh.T. Boymurodov, East. Eur. Sc. J., 4, 44-47 (2015)

4. Kh.T. Boymurodov, East. Eur. Sc. J., 5, 15-19 (2015)

5. A.V. Korniushin, Hydrobiologia, 529(1), 251-270 (2004)

6. P.N. Mamangkey, H.A. Salmon, P.C. Southgate, Aquaculture, 288, 280-284 (2009)

7. Z.I. Izzatullaev, Kh.T. Boymurodov, Byulleten' Moskovskogo Obshchestva Ispytatelei Prirody Otdel Biologicheskii, 121(5), 16-19 (2016)

8. A. Kuzmetov, Ecological-faunistic characteristic of reservoirs' zooplankton in Uzbekistan DSc in Biology dissertation abstract (Tashkent, 2019) 